\title{
PERLINDUNGAN HUKUM BAGI PEKERJA ANAK DI INDONESIA
}

\author{
Made Dharma Laksana Swastika, I Nyoman Putu Budiartha, Desak Gde Dwi Arini \\ Fakultas Hukum Universitas Warmadewa, Denpasar - Bali, Indonesia
}

\begin{abstract}
Abstrak
Peraturan pekerja anak dalam UU 13/2003 untuk pekerja anak di suatu perusahaan dalam praktiknya dapat dikatakan cukup baik dan sesuai dengan perjanjian kerja masing-masing dan harus ada izin dari orang tua anak. Penelitian ini bertujuan untuk mengetahui perlindungan hukum bagi pekerja anak di Indonesia dan mengetahui faktor penyebab anak dibawah umur melakukan pekerjaan. Penelitian ini didesain dengan menggunakan metode hukum empiris. Sumber data didapatkan secara langsung yang berasal dari masyarakat yang dinamakan dengan data primer (data dasar) dan diperoleh dari bahan-bahan pustaka dinamakan data sekunder. Data dikumpulkan dengan menggunakan teknik dokumentasi dan wawancara. Hasil penelitian ini menunjukan bahwa pengaturan pekerja anak dalam Undang-Undang Republik Indonesia Nomor 13 Tahun 2003 bagi pekerja anak dalam suatu perusahaan dalam prakteknya sudah baik dan sesuai perjanjian kerja dari masing-masing dan wajib ada ijin dari orang tua anak tersebut. Dalam mengatasi kendala dan hambatan pihak perusahaan berupaya semaksimal mungkin untuk mewujudkan inti dari pasal 68 Undang-Undang Republik Indonesia Nomor 13 Tahun 2003 dalam hal melarang Perusahaan mempekerjakan pekerja anak yang masih di bawah umur dengan memberikan kebijakan tertentu dengan diberlakukan setelah diadakan musyawarah antara pihak perusahaan dan pekerja anak terlebih dahulu. Melalui penelitian ini diharapkan penyelesaian non litigasi sebagai pilihan utama dan berwibawa (berkeadilan bagi kedua belah pihak) yaitu Pekerja dan Pengusaha diberi keleluasaan untuk memilih juru damai (konsiliator/ mediator) yang ada, serta memfasilitasi terbentuknya system arbitrasi yang bebas/independent, mandiri, dan berwibawa
\end{abstract}

Kata kunci: Indonesia; Pekerja Anak; Perlindungan Hukum;

\begin{abstract}
Child labor regulations in Law 13/2003 for child labor in a company can be said in practice to be quite good and in accordance with their respective work agreements and there must be permission from the child's parents. This study aims to determine the legal protection for child labor in Indonesia and determine the factors causing underage children to do work. This research was designed using empirical legal methods. Sources of data obtained directly from the community called primary data (basic data) and obtained from library materials called secondary data. Data was collected using documentation and interview techniques. The results of this study indicate that the regulation of child labor in the Law of the Republic of Indonesia Number 13 of 2003 for child labor in a company is in good practice and in accordance with the work agreement of each and there must be permission from the child's parents. In overcoming obstacles and obstacles, the company tries as much as possible to realize the core of article 68 of the Law of the Republic of Indonesia Number 13 of 2003 in terms of prohibiting the company from employing underage child labor by providing certain policies to be enforced after deliberation between the company and child labor first. Through this research, non-litigation settlement is expected as the first choice and authoritative (fair for both parties), namely Workers and Employers are given the freedom to choose an existing peace agent (conciliator/mediator), and facilitate the formation of an arbitration system that is free / independent, independent, and authoritative.
\end{abstract}

Keywords: Indonesia; Child Labor; Legal Protection

\section{PENDAHULUAN}

Teknologi yang semakin berkembang memungkinkan anak -anak di bawah umur mempunyai sta tus sebagai pekerja, tuntutan perekonomian hidup bagi keluarga menjadi alasa $\mathrm{n}$ mereka, orang tua tidak mampu memenuhi kebutuhan anak dan juga karena mempunyai hoby sehingga seorang anak terlibat perjanjian pada perusahaan seperti contoh ada artis yang berusia masih anak -anak. Sekarang ini, seorang anak masih di bawah umur dan seora ng anak yang juga membantu dalam mencari nafkah, itu bukan lagi sesuatu yang baru di masyarakat kita, karena pekerja anak sebenarnya memiliki hak dan 
tugas dan peluang baik sebagai warga negara dan sebagai sumber daya untuk pengembangan manusia yang sama $\mathrm{d}$ alam pengembangan di semua bidang.

Fenomena anak -anak yang terlibat dalam partisipasi dalam kegiatan ekonomi, baik bagi mereka yang menerima upah atau tidak, bukanlah hal baru di Indonesia, termasuk di Aceh. Situasi ini meningkat dan terbukti baik karena factor ekonomi keluarga atau kemiskinan dan karena kondisi lingkungan yang mempengaruhi mereka.

Peran orang tua sangat dibutuhkan anak dalam keluarga, baik dari segi motivasi, agar anak dapat tumbuh dan berkembang sesuai dengan kreativitasnya. Nilai -nilai budaya anak akan dikembangkan dalam kehidupan sosial. Karena itu perilaku orang tua sangat berpengaruh pada pertumbuhan dan perkembangan karena keluarga adalah sekolah pertama untuk anak -anak. Dalam hal ini, peran orang tua sangat penting untuk membuat anak -anak yang sukses di masa depan dan yang akan menghindari tindakan tercela di masa depan.

Ini adalah dasar untuk menjaga aturan khusus mengenai pekerja anak yang memerlukan perlindungan hukum sesuai dengan sifatnya sebagai anak, terlepas dari dimana mereka bekerja atau tidak melihat jenis kelamin dan atau jenis pekerjaan mereka dan mempertahankan hubungan kerja dengan mereka yang dipekerjakan. Ini diatur oleh hukum Republik Indonesia, nomor 13 tahun 2003 tentang angkatan kerja. Dalam undang-undang Republik Indonesia tentang Ketenagakerjaan, ia memberlakukan pembatasan pada pekerjaan pekerja anak, berdasarkan pertimbangan bahwa pekerja anak berada pada masa menuntut ilmu, karena generasi berikutnya dan anak -anak nasional berkewajiban untuk menjaga kesehatan mereka dan moralitas dan ketertiban umum.

Beberapa penelitian tentang pekerja anak telah dilakukan oleh peneliti sebelumnya. Pertama, Setiamandani (2012) menyatakan bahwa terjadinya pekerja anak dipengaruhi oleh berbagai faktor sosial seperti kemiskinan, urbanisasi, sosial budaya, pendidikan, perubahan proses produksi serta lemahnya pengawasan dan minimnya lembaga untuk rehabilitasi. Namun pada kenyataannya keterlibatan anak dalam pekerjaan mayoritas didorong oleh faktor kemiskinan atau ekonomi. Kedua, Tarmudzi (2015) menyatakan bahwa persamaan hukum Islam dan Undang-undang, sama- sama melarang mempekerjakan anak di sektor informal, terutama jika syarat-syarat anak bekerja tidak terpenuhi maka itu melanggar hukum, dan perbedaannya anak bekerja hanya terletak pada batasan umur yang di dalam hukum pidana Islam bagi laki-laki 12 (dua belas) tahun, dan 9 (sembilan) tahun bagi perempuan. Selanjutnya, Prajnaparamita (2018) mengemukakan bahwa tenaga kerja anak telah mendapatkan perlindungan yang cukup dari peraturan perundang-undangan di Indonesia. Perlindungan tersebut baik pada tingkat hukum dasar negara (contitutions) dan Undang Undang, maupun pada peraturan derivatif yang dikeluarkan oleh pemerintah pusat, menteri, dan pemerintahan daerah. Terakhir, Izziyana (2019) menyatakan bahwa diperlukan pengawasan dan penegakan hukum serta komitmen masyarakat termasuk juga pengusaha untuk menghilangkan pekerja anak.

Berdasarkan uraian di atas, maka penelitian yang baru ini bertujuan untuk mengetahui perlindungan hukum bagi pekerja anak di Indonesia dan mengetahui faktor penyebab anak dibawah umur melakukan pekerjaan.

\section{METODE PENELITIAN}

Tipe penelitian menggunakan hukum empiris melalui pendekatan konseptual, pendekatan perundangundangan dan pendekatan sosiologis. Sumber data didapatkan secara langsung yang berasal dari masyarakat yang dinamakan dengan data primer (data dasar) dan diperoleh dari bahan-bahan pustaka dinamakan data sekunder (Soekanto \& Mamudji, 2001). Data dikumpulkan dengan metode studi dokumentasi dan wawancara (Hanitjo, 1998).

\section{HASIL PENELITIAN DAN PEMBAHASAN \\ Perlindungan Hukum bagi Pekerja Anak di Indonesia}

Dalam pelaksanaan pembangunan, tenaga kerja di Indonesia memainkan peran yang sangat penting sebagai elemen pendukung untuk keberhasilan pembangunan nasional. Karyawan memiliki hubungan dengan perusahaan, maka merupakan suatu kewajaran apabila perusahaan memberikan perlindungan, pemeliharana dan pengembangan kesejahterana tenaga kerja. Menyadari pentingnya karyawan wanita untuk perusahaan, pemerintah, dan masyarakat, pertimbangan harus diberikan untuk memungkinkan karyawan di Indonesia menjaga keselamatan mereka saat melakukan pekerjaan mereka. Demikian pula, kedamaian dan keselamatan dan kesehatan di tempat kerja harus diupayakan agar me 
mperhitungkan sebanyak mungkin apa yang mereka temui di tempat kerja dan untuk memastikan kewaspadaan saat melakukan pekerjaan. Hubungan kerja disini adalah hubungan yang dilaksanakan antara pekerja anak dengan perusahaan atau perusahaan berdasarkan perjan jian kerja yang telah disepakati oleh kedua belah pihak, dimana isi dari perjanjian kerja pekerja anak tersebut secara substansial memuat mengenai hak dan kewajiban dari masing -masing pihak.

Hubungan kerja terjadi setelah adanya perjanjian kerja yang dibuat oleh pengusaha dengan pekerja anak baik dalam bentuk lisan maupun dalam bentuk tertulis, yang mana isi perjanjian kerja tersebut harus memuat syarat-syarat kerja, serta hak dan kewajiban para pihak dan perjanjian kerja tersebut tidak boleh bertentangan dengan Undang- Undang Ketenagakerjaan dan Perjanjian Kerja Bersama (PKB) atau Peraturan Perusahaan (PP), adapun yang menjadi hak -hak pekerja anak adalah: hak untuk mendapat pekerjaan, dan hak untuk mendapat upah, sedangkan kewajiban dari pekerja anak adalah kewajiban untuk menjalankan perintah yang diberikan oleh perusahaan kepada pekerja, demikian juga hak -hak dari perusahaan adalah berhak untuk memberikan pekerjaan dan perintah kepada pekerja, kemudian kewajiban perusahaan adalah kewajiban memberi upah yan g layak kepada pekerja yang telah menjalankan pekerjaannya (Djumadi, 1988).

Semua perjanjian harus tunduk pada ketentuan undang -undang dalam hal ini Buku III KUH Perdata terutama dalam Pasal 1320 yang menentukan bahwa untuk sahnya suatu perjanjian dipe rlukan empat syarat: Sepakat mereka yang mengikatkan dirinya, cakap untuk membuat suatu perjanjian, Mengenai hal atau objek tertentu, Suatu sebab (causal) yang halal. Apabila ketentuan di atas sudah terpenuhi semua maka suatu perjanjian baik perjanjian $\mathrm{k}$ erja waktu tertentu, maupun perjanjian kerja waktu tidak tertentu, akan dapat dikatakan sah menurut hukum, dan berlaku mengikat sebagai undang -undang bagi pihak yang membuatnya secara khusus.

Kewajiban para pihak dalam suatu perjanjian umumnya disebut dengan prestasi. Dalam hal prestasi ini Soebekti mengatakan Suatu pihak yang memperoleh hak -hak dari perjanjian itu juga menerima kewajiban -kewajiban yang merupakan kebalikan dari hak yang diperolehnya, dan sebaliknya suatu pihak yang memikul kewajiban - kewajiban juga memperoleh hak -hak yang dianggap sebagai kebalikannya kewajiban-kewajiban yang dibebankan kepadanya (Subekti, 1984).

Hasil penelitian tanggal 7 Desember 2019 dengan manager personalia pada Pihak perusahaan dengan pihak pekerja anak, setia p merekrut tenaga kerja dalam bentuk perjanjian kerja waktu tertentu. Hal ini dipertegas pada Undang -Undang Republik Indonesia Nomor 13 Tahun 2003 tentang PKWT, yang menetukan pihak pertama dengan ini menyatakan Pihak Kedua sebagai karyawan/pekerja perusahaan Pihak perusahaan dengan pihak pekerja dalam bidang tugas administrasi dan pengawasan, dan Pihak Kedua dengan ini menyatakan bersedia menjadi karyawan Pihak Pertama dalam bidang tugas administrasi dan pengawasan.

Sebagai pengaturan awal untuk hubungan kerja antara pekerja anak dan perusahaan, perusahaan dan pekerja anak disepakati melalui kontrak kerja jangka tetap dengan kontrak kerja yang disetujui dengan bukti tanda tangan oleh kedua belah pihak sesuai dengan format perjanjian. Dalam format ini hak $\mathrm{d}$ an kewajiban masing -masing pihak dirinci, hak dan kewajibannya adalah hak-hak pekerja anak dalam bekerja di Pihak perusahaan dengan pihak pekerja anak sebagaimana diatur dalam surat perjanjian kerja waktu tertentu dengan lingkup perjanjian kerja waktu tertentu yang menetukan masa percobaan ditetapkan selama 3 bulan dihitung sejak tanggal masuk diterima bekerja (perjanjian kerja waktu tertentu tidak boleh disyaratkan dalam masa percobaan), yakni sejak diterima sebagai pekerja. Upah diberikan secara bulanan, besarnya upah pokok Rp 800.000, dengan waktu kerja sehari 8 jam, atau 48 jam seminggu. Tunjangan-tunjangan di luar upah adalah

a. Tunjangan makan Rp 250.000,-

b. Tunjangan transport Rp 250.000,-

c. Bonus, diberikan sewaktu waktu dengan jumlah yang tidak bisa ditentukan tergantung surplus dari perusahaan

d. Lembur. Uang lembur diberikan dihitung perjam dengan rincian perjam Rp 35.000,-

Secara umum dapat ditegaskan bahwa hak pengusaha adalah mendapatkan hasil pekerjaan dan kewajibannya membayar upah, sedangkan hak pekerja anak adalah menerima pembayaran upah dan kewajibannya melakukan pekerjaan. Dengan demikian, hak pihak yang satu merupakan kewajiban pihak yang lain, demikian juga sebaliknya (Bintang \& Dahlan, 2000). Berdasarkan hasil penelitian tanggal 9 Desember 2019 pihak perusahaan dengan pihak pekerja anak dapat diketahui bahwa perjanjian kerja yang dibuat di perusahaan ini dibuat secara mandiri dalam bentuk tertulis yang berupa 
kontrak baku, dengan masa berlaku selama 1 tahun, dan akan dapat diperpanjang dengan berdasarkan persetujuan kedua belah pihak dan perjanjiannya masih dalam bentuk di bawah tangan karena tidak melalui proses pengesahan ke pejabat yang berwenang, seperti melakukan legalisasi/ gewaarmerkt, ataupun legalisir hal ini dilakukan semata -mata untuk melakukan penghematan baik dari segi biaya maupun dari segi waktu.

\section{Faktor-Faktor Penyebab Anak di bawah Umur Melakukan Pekerjaan}

Implementasinya dalam perusahaan, bahwa anak menurut hukum ketenagakerjaan adalah siapa saja yang berusia di bawah 18 tahun, anak di bawah umur yang bekerja disebabkan beberapa faktor, antara lain adalah karena faktor ekonomi dari anak, mereka berasumsi pekerjaan di perusahaan adalah tidak mengganggu jadwal sekolah. Jadi tidak ada masalah bagi mereka jika mereka terus bekerja dalam kondisi sekolah dan merasa bahwa kegiatan kerja mereka tidak terganggu. Untuk pekerja anak di bawah umur, perusahaan tidak memberikan perlakuan khusus seperti karyawan tersebut dan tidak ada kesempatan yang tepat untuk belajar sambil bekerja. Ini juga didukung oleh fakta bahwa, sebelum mereka pergi bekerja, umumnya bekerja sebagai cleaning service dan waktu setelah kembali dari sekolah yang memiliki izin dari orang tua mereka. Ini juga merupakan hambatan bagi perusahaan untuk menerapkan hukum Republik Indonesia, nomor 13 tahun 2003.

Kehadiran dan etos kerja dari pekerja anak inilah menjadikan pasal 68 Undang-Undang Republik Indonesia Nomor 13 Tahun 2003 tidak dapat diterapkan sepenuhnya dalam suatu perusahaan, dan tetap memerlukan kebijakan tersendiri dari pihak pengusaha dengan kesepakatan yang telah dibuat bersama wakil pekerja anak. Dalam mengatasi kendala dan hambatan tersebut, pihak perusahaan berupaya semaksimal mungkin untuk mewujudkan inti dari pasal 68 Undang- Undang Republik Indonesia Nomor 13 Tahun 2003 sebagai pekerja anak, dengan memberikan kebijakan tertentu dengan diberlakukan setelah diadakan musyawarah antara pihak perusahaan dan wakil pekerja anak terlebih dahulu adalah tanggung jawab pemerintah, dalam hal ini Kementerian Tenaga Kerja, untuk memperhatikan nasib pekerja anak. Perhatian tersebut dapat diberikan dengan secara langsung memberi nasihat kepada pekerja anak tentang pentingnya kesehatan di tempat kerja, khususnya bagi anak-anak sebagai prioritas. Semua upaya ini dilakukan untuk mengimplementasikan dengan benar dan efektif Pasal 68 Undang-Undang Republik Indonesia, nomor 13 tahun 2003, sehingga tidak ada masalah mengenai hak-hak khusus pekerja anak.

Dari hasil penelitian tanggal 10 Desember 2019 bahwa akibat hukum dalam bentuk sanksi yang akan dijatuhkan terhadap pekerja yang melakukan pelanggaran, hal ini telah dipertegas dalam Undang-Undang Republik Indonesia Nomor 13 Tahun 2003 bahwa surat perjanjian kerja waktu tertentu yang menentukan : Apabila pengusaha atau pekerja mengakhiri perjanjian kerja untuk waktu tertentu sebelum waktunya berakhir, maka pihak yang mengakhiri perjanjian kerja tersebut wajib membayar ganti rugi kepada pihak lainnya sebesar sisa upah pekerja sampai waktu atau pekerja seharusnya selesai, kecuali putusnya hubungan kerja karena alasan memaksa/ kesalahan berat pekerja. Segala perselisihan yang timbul akibat perjanjian kerja ini akan diselesaikan secara musyawarah dan mufakat, dan apabila tidak dapat diselesaikan para pihak akan menyelesaikannya melalui Kantor Kepaniteraan Pengadilan Negeri Denpasar.

\section{SIMPULAN DAN SARAN}

1. Simpulan

Pengaturan pekerja anak dalam Undang-Undang Republik Indonesia Nomor 13 Tahun 2003 bagi pekerja anak dalam suatu perusahaan dalam prakteknya sudah baik dan sesuai perjanjian kerja dari masing-masing dan wajib ada ijin dari orang tua anak tersebut. Perusahaan mempekerjakan pekerja anak dalam bidang-bidang tertentu. Hal ini sangat diharapkan oleh Pemerintah pada umumnya serta pengusaha dan pekerja pada khususnya. Pengaturan mengenai perlindungan kerja anak itu memerlukan kebijakan tersendiri dari pengusaha, dimana pihak pengusaha tersebut juga wajib membina hubungan yang baik dengan pihak pemerintah, dalam hal ini adalah pihak Departemen Tenaga Kerja, karena kebijakan dan peraturan-peraturan yang dikeluarkan oleh perusahaan tidak terlepas dari pengawasannya untuk menghindari kemungkinan terjadinya tindakan sewenang-wenang oleh pengusaha terhadap pekerja anak itu sendiri. Kemudian, kendala-kendala dan hambatan yang dihadapi oleh suatu perusahaan dalam menerapkan pasal 68 Undang-Undang Republik Indonesia Nomor 13 tahun 2003, dengan adanya kodrat manusia sebagai makhluk dimana saat-saat tertentu atau 
kondisi tertentu di bidang ekonomi mengalami kondisi keterpurukan, mendorong diberlakukannya Pasal 68 Undang-Undang Republik Indonesia Nomor 13 Tahun 2003 yang diwujudkan dalam bentuk pengecualian. Dalam mengatasi kendala dan hambatan tersebut, pihak perusahaan berupaya semaksimal mungkin untuk mewujudkan inti dari pasal 68 Undang-Undang Republik Indonesia Nomor 13 Tahun 2003 dalam hal melarang Perusahaan mempekerjakan pekerja anak yang masih di bawah umur dengan memberikan kebijakan tertentu dengan diberlakukan setelah diadakan musyawarah antara pihak perusahaan dan pekerja anak terlebih dahulu.

\section{Saran}

Meskipun perjanjian dibuat dalam bentuk perjanjian baku, dimana isi dan ketentuannya sudah diatur sedemikian rupa secara sepihak oleh perusahaan, namun supaya tidak mengurangi makna kebebasan berkontrak dan juga supaya hak pekerja tidak terlalu terabaikan, maka sedikit tidaknya pekerja diberikan kesempatan untuk mengajukan keinginan/ aspirasinya yang selanjutnya dirundingkan secara seksama dan apabila memungkinkan untuk selanjutnya dimasukkan dalam klausula perjanjian kerja, dan juga untuk mencegah ataupun memudahkan penyelesaian apabila terjadi sengketa di kemudian hari, maka akan lebih baik bila perjanjian tersebut disahkan kepada pejabat yang berwenang dan selanjutnya didaftarkan ke dinas tenaga kerja (Disnaker). Selanjutnya, memperkuat penyelesaian non litigasi sebagai pilihan utama dan berwibawa (berkeadilan bagi kedua belah pihak) yaitu Pekerja dan Pengusaha diberi keleluasaan untuk memilih juru damai (konsiliator/ mediator) yang ada, serta memfasilitasi terbentuknya system arbitrasi yang bebas/independent, mandiri, dan berwibawa.

\section{DAFTAR PUSTAKA}

Bintang, S., \& Dahlan. (2000). Pokok-pokok Hukum Ekonomi dan Bisnis. Bandung: PT. Citra Aditya Bakti.

Djumadi. (1988). Hukum Perburuhan Perjanjian Kerja. Jakarta: Sinar Grafika.

Hanitjo, R. (1998). Metodologi Penelitian Hukum dan Jurimetri. Jakarta: Ghalia Indonesia.

Izziyana, W. V. (2019). Perlindungan Hukum bagi Pekerja Anak di Indonesia. Legal Standing: Jurnal Ilmu Hukum, 3(2), 103-115.

Prajnaparamita, K. (2018). Perlindungan Tenaga Kerja Anak. Adminittrative Law \& Governance Journal, 1(Edisi Khusus 1), 112-128.

Setiamandani, E. D. (2012). Perlindungan Hukum Bagi Pekerja Anak Dan Upaya Penanggulangannya. Jurnal Reformasi, 2(2), 74-81.

Soekanto, S., \& Mamudji, S. (2001). Penelitian Hukum Normatif. Jakarta: PT. Raja Grafindo Persada. Subekti, R. (1984). Hukum Perjanjian. Jakarta: PT. Intermasa.

Tarmudzi, M. I. (2015). Perlindungan Hukum Terhadap Pekerja Anak di Sektor Informal. Al-Jinâyah: Jurnal Hukum Pidana Islam, 1(2). 